\title{
Analyzing the Employee Satisfaction and Demand vs Fulfillment of the Food and Beverage Sector in Bangladesh
}

\section{Jamee Ahmad}

MBA, Federation University, Australia; BBA, American International University, Bangladesh; Senior Lecturer, College of Business Administration, International University of Business Agriculture \&TechnologyIUBAT, Dhaka, Bangladesh

\begin{abstract}
This topic is based on finding factors that add value to make a decent workplace, bring equality and serve for a human well-being by implementing features that make people's work life happy and prosperous. A huge part of our population works in the processed food industry. There are companies, which produce food, spice, beverage and other edible materials. The factors that play a vital role in the worker's economic growth, satisfaction, needs' fulfillment and work environment have been identified via open \& close-ended questionnaires. In our country, a lot of research works are based on garments sector but not enough investigations have been conducted on the food and beverage sector. So in this study, the factors that make the employees more productive are identified and their needs vs fulfillment have been tried to analyze. The factors that help them to be more efficient, have been identified and latest needs are also discussed. In this paper, both qualitative \& quantitative methods were used to collect \& process data. A set of close-ended questions were asked to the 115 respondents to prepare the graph and percentages based on their opinion. A qualitative side with open-ended was covered to back up the quantitative side with qualitative answers where the respondent's feelings and observations were focused. At the end of the paper, the factors of employee' satisfaction were identified as pay structure, work hour, employer's behavior, easy access \& goodwill of the company. Inside these factors, a set of questions were asked and it was found that employees are happy but not extremely happy and the number of demands they have made over the years were mostly get satisfied except few. From the qualitative side, the fascinating factors were found where employees requested to have hygiene, refreshment, recreational facilities.
\end{abstract}

Keywords: need, satisfaction, needs fulfillment, employee, work environment.

JEL Classification: J21, J24, J30.

(C) The Author, 2018. This article is published with open access at Sumy State University.

\section{Introduction}

The paper is done based on interviewing the group managers, line managers who are heads of labors and workers, as it wasn't possible to interview each and every labor. So it was done on the supervisors as they usually represent a working unit or a subunit in a production plant. Also, interviews were taken of Shopkeepers in Dhaka city who usually deal with consumers who are seeking for food products from popular companies that are doing business for a long time and has achieved consumer's trust. Job satisfaction is a self-reported positive emotional state resulting from the appraisal of one's job or from job experiences. So the time workers feel that appraisal was done correctly, the results can advance their career, it makes them feel good about their workplace.

\section{Literature Review}

\section{Gary Dessler's theory}

Dessler said, in production firm's incentives play a big role as works are based on units produced. Incentives are paid as the extra amount for over achievement of targets; they are also determinants of satisfaction (Desler, 2005). Benefits of financial and non-financial factors are also strong determinants. Employees feel secure with benefit plans, for example, Supplemental pays: sick leave \& vacation pay, Insurance \& compensation, Retirement: Pensions, Employee services: child-care facilities. The Herzberg's Hygiene-Motivator theory shows two factors for employee welfare. One is a hygiene factor that means providing better workplace, salary, career growth opportunities etc. (Hertzberg, 1959). The second is the motivation factor. It shows the chance for development, sense of achievement and good feedback that boosts up employees motivations level. In the Hygiene factors (extrinsic job) it's said that inadequate working conditions, salary, and incentive pay causes dissatisfaction \& prevents satisfaction. It shows that lack of Hygiene factor can cause employee dissatisfaction; 
even till some extent not following the hygiene factor demotivates employees (Sachau, 2007). It also stated that conditions where employees can freely work without any tension and expect fairness, which would keep them motivated towards their job (Baah, Amoako 2011). Then comes the Motivational factor (intrinsic job), which refers to Job enrichment (challenging job, feedback and recognition) \& addresses higher-level (achievement, self-actualization) needs (Skinner, 1992). It's also been observed that if a preference is given to employee opinion while providing facilities it turns into good motivation (Yousuf, et all 2013).

\section{Maslow's hierarchy of needs}

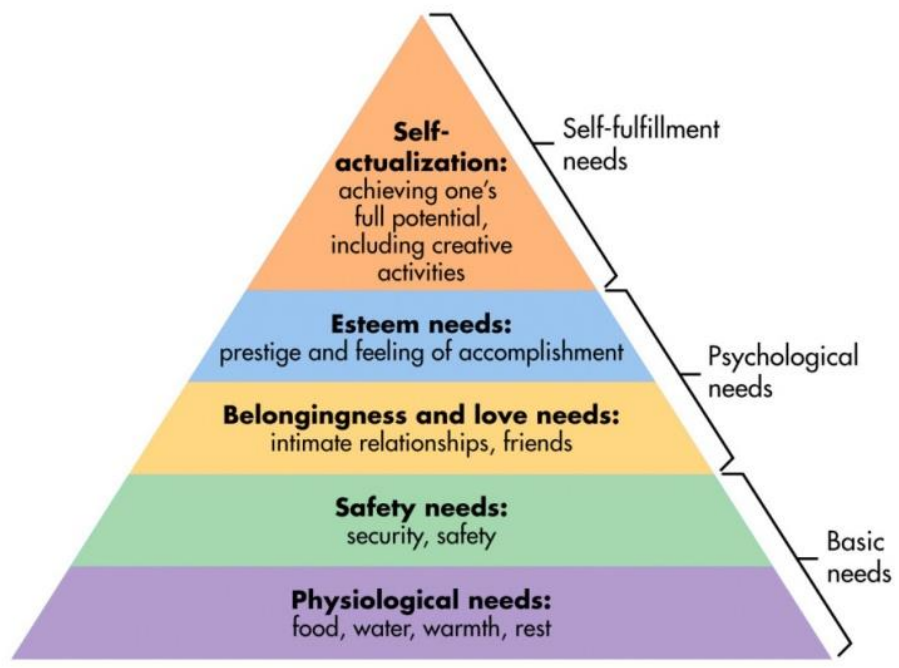

Figure 1. Maslow's hierarchy of needs

Source: simply psychology

Maslow's hierarchy of needs talks about five important factors that human beings want to survive in the society. They are named as physiological needs, safety needs, social/love needs, Esteem needs \& selfactualization (Maslow, 1943). After all these, Psychological needs are satisfying needs of food, shelter, sex and human body needs. According to the Safety need people look for protection from physical and emotional threat, including not only to have security in the society but also in terms of job security, hospitals, peace and prosperity in a neighborhood. Social needs are also important as it stands for acceptance, friendship, affections etc. Esteem is self-respect \& achievement that people feel from inside. Self-actualization gives a person the chance to show full potential and use his/her talent in the work and gives the person a sense of achievement/confidence in himself/herself. A usual worker regardless of his rank tries to satisfy his needs from his job. Now, this report mainly concentrates on how much people are able to satisfy their needs (Taormina, Gao, 2013).

\section{Matching of Maslow's hierarchy of needs with practical needs of workers of the food \& beverage sector}

From previous researches, it was found that workers not only want salary \& other fringe benefits, but also they look for a lifestyle that ensures the proper and stable life. First their job should satisfy basic needs like food, shelter, take them to a position where employees can run their families; all in all, it should satisfy their physiological needs. Then they want safety in the society and also in their job, from the banks they keep their money, safety in terms of having proper healthcare facility etc. After that, they want to be social. Besides earning money for a family they want to communicate with friends, relatives and they need acceptance in the society, which makes them feel valuable (Jerome, 2013). Internal to the job (Esteem) - job is expected to be career growth-oriented, proper facilities to finish the work should be available, respect from peers and environment has to be supportive. External to the job (self-actualization) their job should ensure them their self-respect, they should be able to satisfy the financial needs of the family and get a respected post in the society (Kaur, 2013). 
McGregor's Theory $X \& Y$ and matching with a real scenario

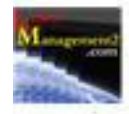

McGregor's Theory $X$ and $Y$

www.learnmanagement2.com
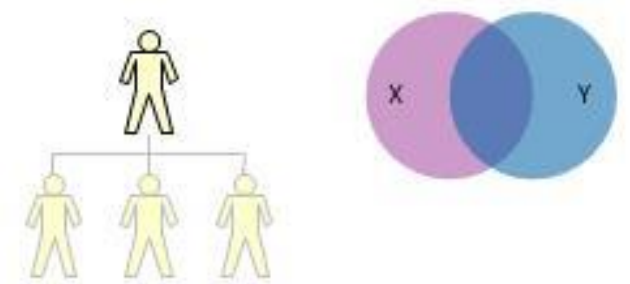

Theory X Management

Believe employees

1. Are lazy

2. Resist Change

3. Do not like responsibility

4. Need pay incentives or threats

5. Disloyal
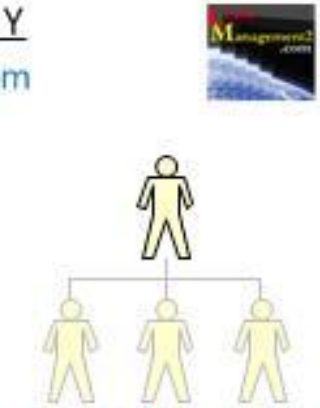

Theory Y Management

Believe employees 1. Are motivated

2. Open to Change

3. Can handle responsibility

4. Prefer rewards over threats

5. Are loyal

Figure 2. McGregor's Theory X \& Y

Source: learn management 2

McGregor's views say "Theory Y" is more reasonable. Theory Y states employees can take their jobs as relaxing, motivating and normal. They give their physical and mental efforts in their jobs. Employees don't need to be threatened, externally controlled or influenced in working effectively; if they have self-direction \& self-control, it's enough to achieve the organizational goals. If the job is rewarding and satisfying, then employees' would be loyal and dedicated to the organization. A regular employee can learn to take his responsibility. In fact, he can take responsibility by himself (McGregor, 1960). In the matching part we can see nowadays the competitiveness and peoples urge to grow financially strong has made men efficient and motivated towards their work. Usually, labors aren't forced to work but they do it happily as it gives them the maximum outcome. (Lawter et.all, 2013). The psychological fulfillment also plays a vital role in the mental satisfaction of employees (Kumar, Mohamed, 2013).

\section{McClelland's Theory of Needs and matching with a real-life scenario}

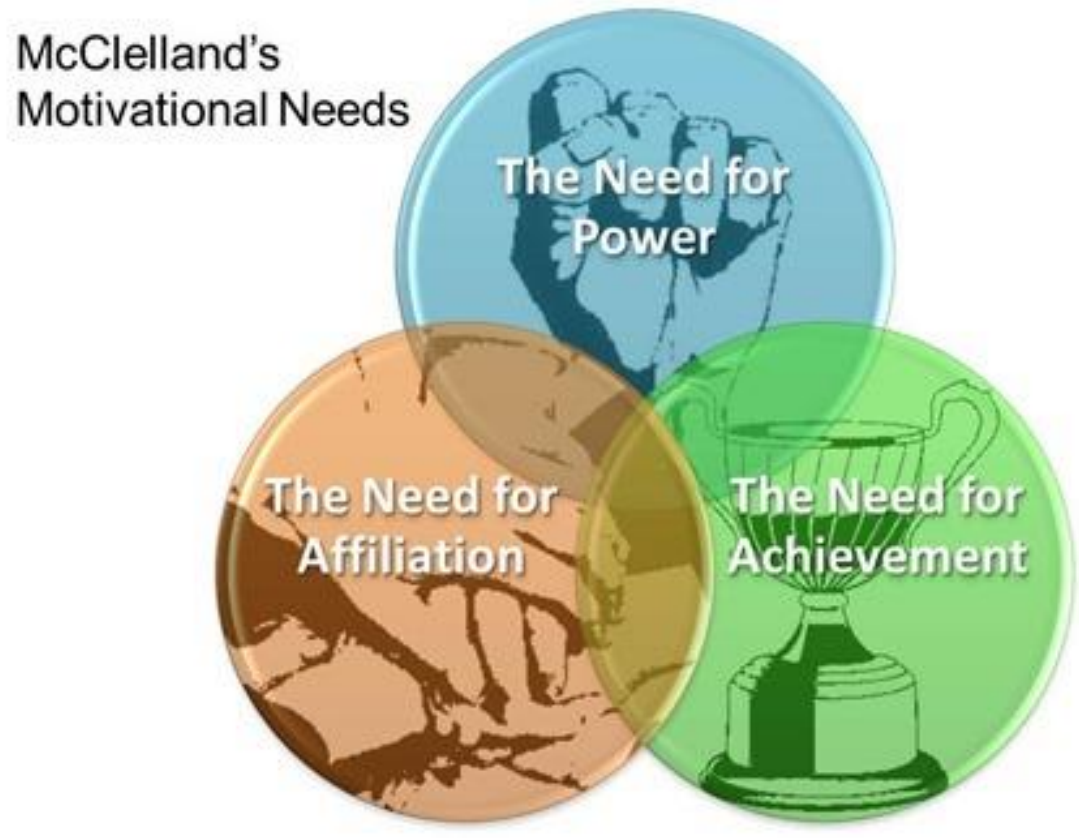

Figure 3. McClelland's Theory of Needs

Source: pocketbook 
Need for achievement (nAch) is the hard work of someone to achieve the set standards to get success. Need for power (nPow) is the way to train and make others behave in a certain way according to the company's need, without this they would not have performed this way. Need for affiliation (nAff) is the urge for close personal and friendly relationship. (Robbins, 2009). In this part, we do understand that the sense of achievement, power and affiliation keeps a human working and they do hope to get these in order to progress in career. In Matching with McClelland's Theory of Needs - it is observed in many cases that employees in the worker class also need power over subordinates and new joiners to train them. It is still a psychological factor to be respected by juniors. They also want good and social relations among them to make the workplace more fun and enjoyable to stay. Many of them believe it helps them to balance their work life and family life. They also thrive for different awards like a worker of the year, best in the section even financial and nonfinancial rewards, these gives them satisfaction in their sense of achievement (Boshoff, 2008). From these, we can understand that labors and workers do work as they have the sense to work hard and earn their living, and comfort. In this report, we have done research on what factors the labors and workers want the most to satisfy their needs and also found how many of it has been fulfilled. It's also found that these three factors can make employees feel accountable for their work and there is a chance for informal accountability based on other's action as well (Royle, Hall, 2012).

\section{Factors and determinants based on previous researches}

A few factors that make the work environment better and gives employees a nice and healthy workplace are pay, working hour, fringe benefit, food and refreshment, transport, healthy and hygienic workplace, compensation (Masood, 2014). Other researchers have shared the idea about few supporting factors that are employer behavior, an appraisal that provides employee better chances to succeed in a career, better facilities, and nice behavior along with motivation from employer and support (Sagger, 2012). It has been found in other research papers that pay, fairness, promotion; working condition of doing the work as factors that keep employees happy (Hossain, 2014). More research on labor management shows factors that make labors satisfied and dissatisfied, which are the holidays, wage provided in time, meal allowance, provident and medical allowance and incentives (Akterrujjaman, 2016). According to a study, it was found that equal benefits and wages, medical allowances, education, house rent and entertainment allowances, yearly leave and festival bonus, weekly holiday, tolerable working hours, job security, life insurance, compensation for accidents, rest breaks during job, good relation with supervisors \& having labor union should be considered as the most important factors to motivate and satisfy the low-skilled employees in an organization. So these can be considered as factors to concentrate as well (Amin, 2016). Even more researches show that salary, other benefits, work environment, are the factors to be analyzed to judge employee satisfaction (Khatun, 2017). Some researchers also show that organizational commitment from the management, supervisory supports are also important factors to consider (Bishwajit, 2016). It's seen in a previous study that HR related outcomes such as job satisfaction, commitment, absenteeism, turnover and even accounting related outcomes such as a profit, sales, a return on investment, a return of assets and organizational outcomes productivity, quality, service are all coming from performance outcomes of HRM strategies. So it can be said that all factors of an organization are affected by HR practices so having a fair employment policy is a must (Khan, 2018).

\section{Research and Findings}

\section{Methodology}

Research type - Quantitative \& Qualitative

Quantitative part - Close-ended MCQs

Qualitative part - the Open-ended comment section

\section{Respondents}

External to the company - shopkeepers - who told us about famous and popular companies (qualitative openended question)

Internal to the company - team leaders, workers/labors from different units, shift managers, factory supervisors, machine operators and process handlers of nine most popular food-processing companies.

Companies surveyed - Dekko foods, Square food \& beverage Ltd, PRAN foods, ACI foods Ltd, Transcom food and beverage, Abdul Monem group, Bombay sweets, PromeAgro foods Ltd, Nabisco Biscuit \& bread co. Ltd.

Number of respondents is 115 . 
The reasons for choosing the open-ended questions are the sector - "employee demand and fulfillment sector is huge and can't be covered by close-ended questions only. Open answers will tell us about the feeling, problems that cannot be counted or measured and the comments give us a clear picture that a number cannot always show.

The paper also consists of the close-ended questions because research requires figures that tell us percentage and number of employees who are putting their opinions. This number and people show the real picture of the human resource of this industry and make the paper more acceptable by other bodies.

So, in order to bring the actual side of employee condition both open \& close-ended questions were asked, company names, respondent identity have not been specifically shown and kept confidential but an overall scenario has been drawn based on actual details.

\section{Findings}

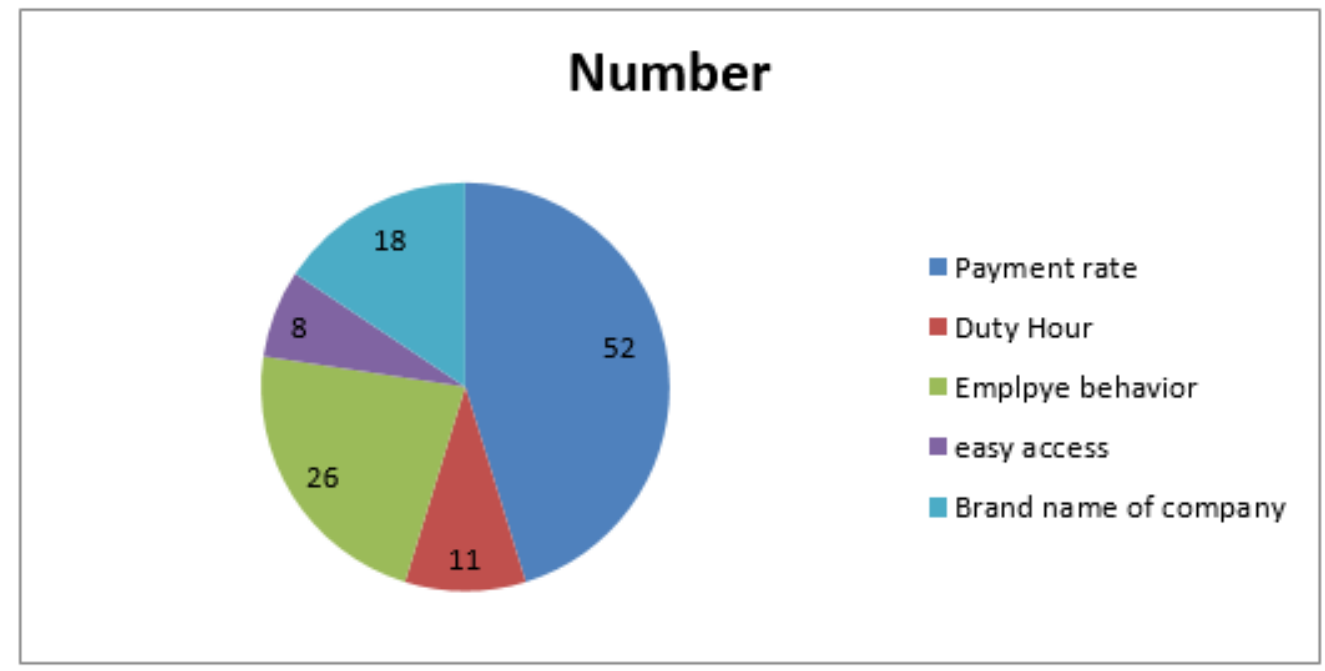

Figure 4. Factors that get first priority

The pie chart shows the first priority for total 115 respondents, out of them 52 have said their first priority in pay rate, 26 workers said for them employer's behavior and attitude matters the most, for 18 people reputation and brand matters the most, and 11 have said their duty hours put most impact of their work life and for 8 its near to their home.

Table 1. Factors of the job that get most priority according to the respondents (in percentage)

\begin{tabular}{|l|c|c|}
\hline \multicolumn{1}{|c|}{ Variable } & Percentage & Frequency \\
\hline Pay rate & $45 \%$ & 52 \\
\hline Employers behavior & $22.6 \%$ & 26 \\
\hline Brand name & $9.5 \%$ & 18 \\
\hline Duty hours & $15.6 \%$ & 11 \\
\hline Easy access & $3 \%$ & 8 \\
\hline
\end{tabular}

From these findings, we can see that employees give the most preference to the "pay rate" \& "employer's behavior", nowadays people are getting more conscious about their rights and fair treatment. On the third place its "duty hours" getting priority by the labor/employees and managers. The less common priorities are a brand name of the company and easy access.

\section{Findings regarding work hours}

Table 2. Employees' extra hour work preference

\begin{tabular}{|l|c|c|}
\hline \multicolumn{1}{|c|}{ Variable } & Percentage & Frequency \\
\hline Always & $51 \%$ & 59 \\
\hline Some time & $32.48 \%$ & 37 \\
\hline Never & $16.52 \%$ & 19 \\
\hline
\end{tabular}

Findings from the open-ended comment section: 
It's been found that employees do prefer working extra hours, only if they get extra hour rate (found in qualitative questioning);

But some organizations do not always request employees to work overtime, only during excess demand of product they request employees to stay work longer than usual hours;

But few employees do think they are made to work more but aren't getting paid for overtime but the shift managers/supervisors say they work overtime not as extra work but for the work they couldn't finish in proper time and couldn't meet the expected standard as they were making too many mistakes or for being slow.

\section{Findings regarding the payment}

Table 3. Employees are satisfied with a per hour pay rate

\begin{tabular}{|l|c|c|}
\hline \multicolumn{1}{|c|}{ Variable } & Percentage & Frequency \\
\hline Yes & $17.39 \%$ & 20 \\
\hline It's ok (Average) & $68.69 \%$ & 79 \\
\hline No & $13.91 \%$ & 16 \\
\hline
\end{tabular}

From the above calculations, we can see that most of the employees think that their payment is "ok" or "average". Then the second highest employees find it as good. Then a few percentages say they are not satisfied with their pay rate. From the qualitative question, we got to know that a pay rate varies from the company to company and the department to department and most of the labors are positive about it.

Table 4. Employees get paid for over time \& the pay rate is more than usual hours

\begin{tabular}{|l|c|c|l|c|c|}
\hline Over time & \multicolumn{1}{|c|}{ Pay rate } & \multicolumn{2}{c|}{ Percentage } & Frequency \\
\hline \multicolumn{1}{|c|}{ Variable } & Percentage & Frequency & \multicolumn{1}{c|}{ Variable } & $64.34 \%$ & 74 \\
\hline Always & $70.43 \%$ & 81 & Always & $28.69 \%$ & 33 \\
\hline Occasionally & $22.60 \%$ & 26 & Occasionally & $6.95 \%$ & 8 \\
\hline No & $6.95 \%$ & 8 & No & \\
\hline
\end{tabular}

From the calculations we can understand that most of the labors/workers $(70 \%)$ do get paid for working extra hours, $22 \%$ say they do get paid occasionally and sometimes don't get paid and about $6.9 \%$ say they don't get paid at all for overtimes;

About the pay rate, we can find that $64 \%$ are saying they usually get more than regular hours, $28 \%$ say occasionally they get more than regular times and about $6.9 \%$ say their payment isn't more than regular hours;

$>$ From our qualitative questions, we got to know that companies do provide extra money "occasionally" like festival times, company's anniversary or due to excessive labor demands.

\section{Regarding other benefits}

Table 5. Employees get leaves when they want

\begin{tabular}{|c|c|c|}
\hline Always & Sometimes & Never \\
\hline 29 & 70 & 16 \\
\hline
\end{tabular}

We can see in the above chart that 70 workers have said that they do get leaves but sometimes not always, and 29 are saying they always get leaves and 16 said it's hard to get leaves and usually don't get leaves.

Finding from the open comment sections show:

It has been found workers do get leaves but not whenever they want. From the qualitative comment section, we get to know that if they show proper documents or have a good attendance record based on that emergency leaves are granted after asking;

If leaves are enjoyed then medical and other papers and documents are checked;

If the employees/workers fail to show proper reason and papers, then the wage/salary is deducted, in case of emergency it may be waved like nationwide strikes, labor union issues.

Table 6. Employees are given transportation and food \& refreshment

\begin{tabular}{|l|c|c|l|c|c|}
\hline Transportation & \multicolumn{2}{|c|}{ Food \& refreshment } \\
\hline \multicolumn{1}{|c|}{ Variable } & Percentage & Frequency & \multicolumn{1}{c|}{ Variable } & Percentage & Frequency \\
\hline Always & $13 \%$ & 15 & Always & $47.82 \%$ & 55 \\
\hline Sometimes & $10.43 \%$ & 12 & It's ok & $35.65 \%$ & 41 \\
\hline No & $76.52 \%$ & 88 & No & $16.52 \%$ & 19 \\
\hline
\end{tabular}


It has been calculated that $13 \%$ of the workers get transportation two times a day, $10 \%$ gets occasionally and $76 \%$ aren't getting any transport facility from the employers.

Findings from the qualitative open-ended question:

Usually big and famous organizations with a large number of workers do provide transport buses that start the journey from common bus stops to the workplace \& in the evening drop the workers at the same stoppage, employees are to take a bus and are to be dropped at the same place;

Sometime when employees need to work overtime to fulfill huge orders then company hires transport buses to make employees reach home at late hours, its occasional and isn't always available;

But the quality of the buses isn't satisfactory, and they are overloaded with people against 30 seats the passenger number is 50, so a lot of workers have to travel standing up.

\section{Regarding the behavior}

Table 7. Employees get nice behavior from the boss

\begin{tabular}{|c|c|c|}
\hline Always & Sometimes & Never \\
\hline 86 & 17 & 12 \\
\hline
\end{tabular}

This simple calculation shows that 86 respondents are treated nicely by their supervisor/floor managers. 17 have mentioned sometimes they are treated well and sometimes not, 12 said they commonly get the poor and rude behavior.

From the open-ended section it's been found that usually organizations have the policy to be nice and tolerant towards employees so in those particular places warning and instruction are given in a diplomatic way, so even the harshest decision is also given in a polite manner;

But where there are just oral instructions from the authority on behavior, in those places the usual attitude is good but sometimes due to excess pressure or poor work quality the supervisors lose their cool and behave in an unacceptable way;

But there are organizations where employee treatment is not satisfying and employees aren't happy with it and they want proper behavioral codes to be made.

Table 8. Does your organization's politics hamper your work life?

\begin{tabular}{|c|c|c|}
\hline Always & Sometimes & Never \\
\hline 12 & 25 & 78 \\
\hline
\end{tabular}

Here we can see that 12 employees have said they do get affected by internal politics, 25 said sometimes they are hampered and 78 said it didn't affect them.

From the open-ended section:

Employees said that few attempts from peers to impress the boss hamper them, these disliked attempts are telling employees practices to the boss in a different manner, sometimes lie to the boss to impress him and badmouthing about other employees;

To get promoted some employees suggest unnecessary and irrelevant changes that put other in trouble;

They suggest cost-cutting, which reduces chances for increment.

Table 9. Employees are blamed for something they are not responsible for

\begin{tabular}{|c|c|c|}
\hline Always & Sometimes & Never \\
\hline 17 & 21 & 77 \\
\hline
\end{tabular}

Inside the hectic, humid environment of processing factories its common the works sometimes get messed up and employees are blamed unnecessarily by floor manager/ supervisors;

17 workers believe that a supervisor blames them for everything, 21 believe that sometimes they have to take the responsibility for junior workers or for the mistake done by line managers and 77 (the majority) find that they aren't actually taking the blame for others.

Table 10. Employees are happy with the behavior of the peers \& boss towards them

\begin{tabular}{|c|c|c|}
\hline Always & Sometimes & Never \\
\hline 62 & 38 & 15 \\
\hline
\end{tabular}


Findings from the survey and the open-ended section:

62 pupils are happy with their superior's behavior, 38 people find that bosses are usually nice, but whenever they find the error in works they behave rudely;

15 workers think bosses are not nice with them and they are always rude because supervisors think putting more pressure and keeping employees in fear will make them more efficient, which actually doesn't work, and creates workplace dissatisfaction.

Table 11. The organization has proper health \& safety equipment

\begin{tabular}{|c|c|c|}
\hline Always & Sometimes & Never \\
\hline 90 & 10 & 5 \\
\hline
\end{tabular}

About 90 workers find their workplace has a proper number of health and safety equipment, 10 say sometimes they have enough \& sometimes they don't, which they expressed as the fire extinguishers are expired and first aid boxes aren't checked regularly, whenever new boxes and cylinders arrive only then they find it in a good condition. And 5 said in their department they don't have these facilities because the authority thinks in those parts it's not mandatory by the government to have the equipment.

Table 12. The organization pays for treatments of employees in case of any accident at the workplace

\begin{tabular}{|c|c|c|}
\hline Always & Sometimes & Never \\
\hline 82 & 20 & 13 \\
\hline
\end{tabular}

82 workers say their employer pays for their workplace injuries, 20 say sometimes they get paid and 13 say they never get paid.

Findings from open questions:

Employees in certain big organizations say they always get treatment money, or the doctor who is always available on the site treats them and the company provides money for medicines based on the prescription; 20 employees who said sometimes they are paid for accident actually mean that based on the seriousness of the injury they are paid, if it's a small cut the supervisor doesn't pay much attention, if its serious enough and a worker needs to be taken to the hospital only then after checking papers and documents company pays the money;

13 said they never get paid after injury as it was too small.

Table 13. Demands made from labors 2014-2016

\begin{tabular}{|l|c|c|c|c|c|}
\hline \multicolumn{1}{|c|}{ Factors } & $\begin{array}{c}\text { Number of } \\
\text { requests to revise }\end{array}$ & Accepted & Rejected & $\begin{array}{c}\text { Partially } \\
\text { accepted }\end{array}$ & $\begin{array}{c}\text { No result/ } \\
\text { pending }\end{array}$ \\
\hline Pay & 11 & 8 & 1 & 1 & 1 \\
\hline Work hours & 7 & 6 & 1 & $\mathrm{x}$ & \\
\hline Facilities (foods) & 3 & $\mathrm{x}$ & $\mathrm{x}$ & 2 & 1 \\
\hline $\begin{array}{l}\text { Facilities (washroom, } \\
\text { prayer room) }\end{array}$ & 5 & 1 & 2 & 1 & 1 \\
\hline Holidays & 17 & $\mathrm{x}$ & 3 & 5 & 9 \\
\hline
\end{tabular}

This chart shows the number of requests made by the employees to their employers and facilitates they asked for. The calculations show how much has been done and how much has been fulfilled, rejected and pending the decision.

Table 14. Overall satisfaction of employees

\begin{tabular}{|l|c|c|c|c|c|}
\hline & V. Happy & Happy & Neither happy nor sad & Sad & V. sad \\
\hline Frequency & 11 & 64 & 25 & 8 & 7 \\
\hline Percentage & $9.56 \%$ & $55.65 \%$ & $21.73 \%$ & $6.95 \%$ & $6.08 \%$ \\
\hline
\end{tabular}

This chart shows the overall satisfaction level of the employees in this sector. About $9.56 \%$ are very happy and satisfied, $55.65 \%$ are just happy, $21.73 \%$ are on the average side, $6.95 \%$ are sad and $6.08 \%$ are very sad about their facility demands fulfilled.

\section{Decision}

We can see that most of the employees are on the positive side, so we can understand that this food-processing sector is doing well in terms of employee welfare, still there are some chances to do better if employee requests are entertained. 
More findings from the open-ended comment section:

Food hygiene and cleanliness at work sites are maintained properly;

$>$ Organizations have safety training \& safety gears for all but the quality's not up to the marl;

$>$ The organization arranges picnics, tours, parties and has other recreational activities for employees;

$>$ Logical demands were fulfilled by the authority but sometimes the company fails to fulfill demands because of not having enough to give to the workers;

$>$ Food refreshments are provided almost at all the companies;

$>$ Prayer room, washrooms are there but not sufficient in number.

\section{Conclusion}

After analyzing all the data it can be claimed that the food \& beverage processing sector has kept its workers happy but it was also found that almost every demand is getting fulfilled but not to the expected limit, properly following government rules and researches like this will help this sector grow more, and other industrial sectors could be more stable and nice by benchmarking the food processing sector. This report will help factory managers to know their employees better and will bring satisfaction if properly followed. In this modern era of human rights and employee satisfaction, it is expected that it would help labors. In future employee/labor satisfaction can be measured and new factors that make them happy can be identified in order to make a workplace better.

The main objective of this research was to find out the condition of the food processing sectors employees, due to lack of communication and financial support of the student who went to the field with survey papers, could talk to a huge number but the information is solid and represents actual scenery of the employees. It is expected that this paper will open doors for the new and more concentrated researches in this area that needs attention. We can expect that the purpose of this report has been served as it was able to find opinions of important numbers or workers, supervisors and floor managers. In future, more researches could be done on measuring the quality of the facilities, more features that makes the workplace a better experience and more organizations could be included who are not famous or big but are in the same industry operating in local areas only.

\section{References}

1. Amin, R. (2016). Job Satisfaction of Low-skilled Employees of Manufacturing Industry in Bangladesh: A Case Study. Journal of Investment and Management, 166-170.

2. Bishwajit, M. K. A. (2016). Relationships between organizational commitments, supervisory support and job satisfaction of nurses in a public specialized hospital, Bangladesh. Bangladesh Journal of Medical Science, 39-44.

3. Boshoff, C. A. C. (2008). The influence of McClelland's Need Satisfaction Theory on Employee Job Performance. Journal of African Business, 55-81.

4. Desler, G. (2005). Human Resource Management. New York: Prentice Hall Inc.

5. Herzberg, F. (1959). Two factor theory. The Motivation to work ( $2^{\text {nd }} E d$.). New York: John Wiley.

6. Hossain, S. (2014). Job Satisfaction of Bank Employees in Bangladesh. Social Science Research Network, 1-10.

7. Jerome, D. N. (2013). Application of the Maslow's hierarchy of need theory; impacts. International Journal of Business and Management Invention, 39-45.

8. Kaur, A. (2013). Maslow's Need Hierarchy Theory: Applications \& Criticism. Global Journal of Management \& Business Studies, 1061-1064.

9. Khan, Y. H. (2018). Strategic Human Resource Practices and its Impact on Performance towards Achieving Organizational Goals. Performance towards Achieving Organizational Goals, 66-73.

10.Khatun, M. (2017). Employee Satisfaction: A Case Study of Information and Communication Technology Sector in Bangladesh. International Journal of Advanced Research, 1375-1383.

11.Kwasi Dartey-Baah, G. K. (2011). Application of Frederick Herzberg's Two-Factor theory in assessing and understanding employee motivation at work: a. European Journal of Business and Management, 1-9.

12.Lawter, L. K. R. (2015). McGregor's Theory X/Y \& Job Performance: A multilevel, multi-source Analysis. Journal of Managerial Issues, 84-101.

13.M. Todd Role, A. T. (2012). The Relationship Between McClelland's Theory of Needs, Feeling Individually. International Journal of Management and Marketing Research, 21-42.

14.Maslow, A. (1943). A Theory of Human Motivation. Psychological Review. 
15.Masood, A. Q. (2014). Factors Affecting Employee Satisfaction of the Public and Private Sector Organizations of Pakistan. International Journal of Human Resource Studies, 97-121.

16.McGregor, D. (1960). The Human Side of Enterprise. USA: McGraw Hills.

17.Ramesh Kumar Moona Haji Mohamed, D. C. (2013). The Relationship between McGregor's X-Y Theory. International Journal of Academic Research in Business and Social Sciences, 715-720.

18.Robert J. Taormina, J. H. (2013). Maslow and Motivation Hierarchy: Measuring satisfaction of the needs. American Journal of Psychology, 155-177.

19.S.M. Akterujjaman, M. H. (2016). Workers' Satisfaction toward RMG Industry in Bangladesh: A Study on Dhaka and Gazipur City. International Journal of Research in Management \& Business Studies, 22-30.

20.Sachau, D. A. (2007). Resurrecting the Motivation-Hygiene Theory: Herzberg and the Positive Psychology Movement. Human Resource Development Review.

21.Sagger, A. R. (2012). Identification of Variables Affecting Employee Satisfaction and Their Impact on the Organization. IOSR Journal of Business \& Management, 32-39.

22.Seteven J. Skinner, J. M. (1992). Business for 21 st Century. New York: Prentice Hall inc.

23.Stephen P. Robbins, T. L. (2009). Organizational Behavior. Prentice Hall.

24.Wan Fauziah Wan Yusoff, T. S. (2013). Herzberg's Two Factors Theory on Work Motivation: Does Its. Global Journal of Commerce \& Management Perspective, 18-23. 